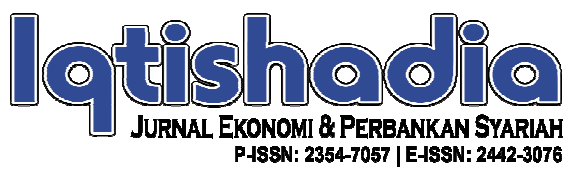

\title{
Pengaruh Dimensi Akses Dan Penggunaan Pada Keuangan Inklusif Terhadap Profitabilitas Unit Usaha Syariah Di Indonesia Periode 2017-2019
}

\author{
Siti Mumainnah ${ }^{1}$, Uly Mabruroh Halida ${ }^{2}$ \\ 1), 2) Institut Agama Islam Negeri Madura, Indonesia \\ Email: ulyhalida@iainmadura.ac.id
}

\begin{abstract}
Abstrak:
Saat terjadinya krisis keuangan global yang terjadi tahun 1998, krisis tahun 2008, dan krisis di Eropa tahun 2011, telah membuat industri perbankan Eropa anjlok. Namun, beberapa negara di Asia justru mengalami pertumbuhan. Pertumbuhan ekonomi Asia ternyata belum didukung oleh akses masyarakat terhadap lembaga keuangan. Akses masyarakat Indonesia terhadap lembaga keuangan juga masih rendah karena terjadinya kesenjangan bagi masyarakat menengah yang belum terbiasa dengan akses perbankan (unbanked). Untuk memperluas akses layanan keuangan diluncurkanlah program keuangan inklusif (financial inclusion). Penelitian ini bertujuan untuk mengetahui pengaruh dimensi akses dan penggunaan pada keuangan inklusif terhadap profitabilitas Unit Usaha Syariah di Indonesia periode 2017-2019 baik secara parsial maupun simultan. Metode penelitian menggunakan penelitian kuantitatif. Jenis penelitian menggunakan asosiatif. Analisis data menggunakan analisis regresi linier berganda. Jenis data dalam penelitian ini adalah data sekunder. Objek dalam penelitian ini adalah Unit Usaha Syariah di Indonesia. Populasi dalam penelitian ini adalah capaian statistik perbankan Syariah yang diterbitkan oleh OJK dan data jumlah penduduk yang diterbitkan oleh BPS. Pengambilan sampel dalam penelitian ini adalah menggunakan sampel jenuh. Hasil penelitian ini menunjukkan bahwa dimensi akses pada keuangan inklusif tidak berpengaruh terhadap profitabilitas, dapat dilihat dari nilai thitung $1,130<$ ttabel 2,03224. Sedangkan dimensi akses pada keuangan inklusif berpengaruh negatif terhadap profitabilitas, dapat dilihat dari nilai thitung $-4,612>$ ttabel 2,03224,. Secara simultan, dimensi akses dan penggunaan pada keuangan inklusif berpengaruh terhadap profitabilitas, dapat dilihat dari nilai Fhitung sebesar 32,486> Ftabel 3,28.
\end{abstract}

Kata kunci : Dimensi Akses, Dimensi Penggunaan, Keuangan Inklusif, Profitabilitas

\begin{abstract}
:
During the global financial crisis that occurred in 1998, the crisis in 2008, and the crisis in Europe in 2011, the European banking industry plummeted. However, several countries in Asia are experiencing growth. Asia's economic growth has not been supported by public access to financial institutions. Indonesian people's access to financial institutions is also still low due to the gap for the middle class who are not used to banking access (unbanked). To expand access to financial services, a financial inclusion program was launched. This study aims to determine the effect of the dimensions of access and use on financial inclusion on the profitability of Islamic Business Units in Indonesia for the 2017-2019 period, either partially or simultaneously.The research method uses quantitative research. This type of research uses associative. Data analysis used multiple linear regression analysis. The type of data in this study is secondary data. The object of this research is the Sharia Business Unit in Indonesia.
\end{abstract}

http://ejournal.iainmadura.ac.id/index.php/iqtishadia

DOI: 10.1905/iqtishadia.v8i2. 5196 
The population in this study is the achievement of Islamic banking statistics published by OJK and population data published by BPS. Sampling in this study is to use a saturated sample. The results of this study indicate that the dimension of access to financial inclusion has no effect on profitability, it can be seen from the value of tcount $-1.130<$ ttable 2.03224 . While the dimension of access to financial inclusion has a negative effect on profitability, it can be seen from the value of tcount $-4.612>$ ttable 2.03224. Simultaneously, the dimensions of access and use of financial inclusion have an effect on profitability, it can be seen from the Fcount value of 32.486> Ftable 3.28.

Keywords : Access Dimension, Usage Dimension, Financial Inclusion, Profitability

\section{PENDAHULUAN}

Krisis keuangan global yang terjadi tahun 1998, krisis tahun 2008, dan krisis di Eropa tahun 2011, telah membuat industri perbankan Eropa anjlok. Keadaan perekonomian ini membuat kekuatan perekonomian dunia beralih dari Barat ke Timur, khususnya Asia. Saat terjadinya krisis ini, beberapa negara di Asia justru mengalami pertumbuhan. ${ }^{1}$

Pertumbuhan ekonomi Asia ternyata belum didukung oleh akses masyarakat terhadap lembaga keuangan. Akses masyarakat Indonesia terhadap lembaga keuangan juga masih rendah karena terjadinya kesenjangan bagi masyarakat menengah yang belum terbiasa dengan akses perbankan (unbanked). Berdasarkan data dari World Bank pada tahun 2011, Global Financial Inclusion Index memaparkan bahwa Financial Inclusion Index Indonesia hanya $19.6 \%$. Ini masih jauh di bawah negara-negara lain seperti Malaysia $66.7 \%$, Philipina $26.5 \%$, Thailand $77.7 \%$, Vietnam $21.4 \%$, India $35.2 \%$, China $63.8 \%$, Rusia $48.2 \%$, dan Brazil $55.9 \%{ }^{2}$ Tingginya unbanked people disebabkan karena garis kemiskinan antara provinsi, rendahnya pembiayaan UMKM, suku bunga kredit mikro tinggi, asymmetric information, kemampuan manajemen UMKM kurang memadai, monopoli bank pada sektor mikro dan terbatasnya saluran distribusi jasa keuangan. ${ }^{3}$ Inilah yang menjadi alasaan pentingnya penerapan keuangan inklusif.

Istilah Financial Inclusion atau Keuangan Inklusif menjadi tren pasca krisis 2008 yang didasari pada dampak krisis terhadap kelompok in the bottom of the pyramid (pendapatan rendah dan tidak teratur, tinggal di daerah terpencil, orang cacat, buruh yang tidak mempunyai dokumen identitas legal, dan masyarakat pinggiran) yang umumnya unbanked dan tercatat dengan pertase sangat tinggi di luar negara maju ${ }^{4}$ Menurut Otoritas Jasa Keuangan $(\mathrm{OJK})$, keuangan inklusif adalah sebagai upaya yang bertujuan untuk meniadakan segala bentuk hambatan yang bersifat harga maupun non harga terhadap akses mayarakat dalam memanfaatkan layanan jasa keuangan sehingga dapat memberikan manfaat yang signifikan terhadap peningkatan taraf hidup masyarakat terutama untuk daerah dengan wilayah dan kondisi geografis yang sulit dijangkau atau daerah perbatasan.

1 Dede Aji Mardani, "Peran Perbankan Syariah Dalam Mengimplementasikan Keuangan Inklusif Di Indonesia," Al-Afkar: Journal for Islamic Studies, 1, 1 (Januari 2018): 105-6.

2 Aji Mardani, 106.

3 Hairatunnisa Nasution, Yasir Nasution,dkk, "Analisis Financial Inclusion Terhadap Pemberdayan Mayarakat Miskin di Medan (Studi Kasus Pembiayaan Mikro SS II di Bank Sumut Syariah)," j-EBIS: Jurnal Ekonomi dan Bisnis Islam, 1, 2 (April 2017): 2.

4 "Keuangan Inklusif di Indonesia - Bank Sentral Republik Indonesia," diakses dari, https://www.bi.go.id/id/perbankan/keuanganinklusif/Indonesia/Contents/Default.aspx pada tanggal 9 April 2021 pukul 11.09 WIB.

Iqtishadia: Jurnal Ekonomi dan Perbankan Syariah 
Program financial inclusion di Indonesia di luncurkan pada tahun 2010. Bank Indonesia meluncurkan program National Strategy for Financial Inclusion (NSFI) sebagai upaya untuk memperluas akses masyarakat terhadap jasa keuangan terhadap masyarakat yang membutuhkan akses lembaga keuangan (unbanked). Program keuangan inklusif di Indonesia telah diatur dalam Peraturan Presiden Republik Indonesia Nomor 82 Tahun 2016 tentang Strategi Nasional Keuangan Inklusif yang dikeluarkan pada 7 September 2016. Peraturan ini merupakan landasan hukum dan pedoman dalam melaksanakan program keuangan inklusif di Indonesia.

Pengukuran terhadap inklusi keuangan telah dilakukan sebanyak tiga kali setiap tiga tahun sekali, yaitu tahun 2013, 2016, dan 2019. Pengukuran ini dilakukan oleh Suvei Nasional Literasi dan Inklusi Keuangan dan OJK. Hasil pengukuran ini menunjukkan bahwa keuangan inklusif mengalami peningkatan. Pada tahun 2013 sebesar 59,70\%. Kemudian pada tahun 2016 mengalami peningkatan sebesar 8,10\% sehinngga tingkat keuangan inklusif menjadi 67,80\%. Terakhir, pada tahun 2019 mengalami peningkatan lebih besar lagi, yaitu 8,39\% yang membuat tingkat keuangan inklusif menjadi 76,19\%.

Indeks Keuangan Inklusif (IKI) adalah salah satu cara alternatif untuk pengukuran keuangan inklusif yang menggunakan indeks multidimensional berdasarkan data makroekonomi, terutama pada jangkauan layanan sektor perbankan. Pengukuran IKI pada dasarnya merupakan upaya yang dilakukan Bank Indonesia untuk mengkombinasikan berbagai indikator sektor perbankan, sehingga pada akhirnya IKI dapat menggabungkan beberapa informasi mengenai berbagai dimensi dari sebuah sistem keuangan yang inklusif, yaitu akses (access), penggunaan (usage), dan kualitas (quality) dari layanan perbankan. Dimensi Akses adalah dimensi yang digunakan untuk mengukur kemampuan penggunaan jasa keuangan formal sehingga dapat dilihat terjadinya potensi hambatan untuk membuka dan menggunakan rekening bank, seperti biaya atau keterjangkauan fisik layanan jasa keuangan (kantor bank, ATM, dan sebagainya). Dimensi Penggunaan adalah dimensi yang digunakan untuk mengukur kemampuan penggunaan aktual produk dan jasa keuangan, antara lain terkait keteraturan, frekuensi, dan lama penggunaan. Dimensi Kualitas adalah dimensi yang digunakan untuk mengetahui apakah ketersediaan atribut produk dan jasa keuangan telah memenuhi kebutuhan pelanggan. ${ }^{5}$

Pada tahun 2016 dilakukan pengukuran keuangan inklusif tiap sektor keuangan, termasuk industri keuangan Syariah oleh Survei Nasional Literasi dan Inklusi Keuangan. Sektor tertinggi ada pada perbankan syariah dengan tingkat keuangan inklusif sebesar 9,6\%. Hal ini menunjukkan bahwa perbankan syariah merupakan lembaga yang paling efektif dalam mengimplementasikan keuangan inklusif di Indonesia. Perbankan Syariah terdiri dari Bank Umum Syariah (BUS), Unit Usaha Syariah (UUS), dan Bank Pembiayaan Rakyat Syariah (BPRS).

Pada tahun 2019 Indonesia telah memiliki 14 Bank Umum Syariah (BUS), 20 Unit Usaha Syariah (UUS), dan 165 Bank Pembiayaan Rakyat Syariah (BPRS).6Perkembangan ini merupakan bukti bahwa perbankan syariah mampu bertahan meskipun di tengah instabilitas ekonomi, seperti krisis 1998, 2008, dan krisis yang melanda Eropa pada 2011. Pertambahan

5 Bank Sentral Republik, "Indeks Keuangan Inklusif," diakses dari https://www.bi.go.id/id/perbankan/keuanganinklusif/indikator/indeks/contents/default.aspx pada 6 November 2020 pukul 12.07 WIB.

6 Otoritas Jasa Keuangan, “Snapshot Perbankan Syariah Indonesia 2019," Otoritas Jasa keuangan, Maret 2019.

178 
jumlah ini sudah menyentuh lapisan masyarakat dari pusat hingga ke daerah. Untuk mengukur keberhasilan perbankan syariah dalam menerapkan keuangan inklusif dapat diukur salah satunya menggunakan kinerja keuangan. Keadaan kinerja keuangan digunakan sebagai bahan pertimbangan dalam pengambilan kebijakan manajerial dari segala aspek dalam dunia perbankan. Informasi yang disajikan dalam kinerja keuangan dapat digunakan oleh pihak-pihak yang terkait baik investor, kreditor, dan pihak-pihak luar perbankan untuk memprediksi kinerja keuangan yang sebenarnya pada setiap periode. ${ }^{7}$

Salah satu cara untuk mengukur kinerja keuangan yaitu dengan menggunakan analisis rasio keuangan. Analisis rasio keuangan merupakan aktivitas untuk menganalisis laporan keuangan dengan cara membandingkan satu akun dengan akun lainnya yang ada dalam laporan keuangan, perbandingan tersebut bisa antar akun dalam laporan keuangan neraca maupun rugi laba. ${ }^{8}$ Penelitian ini akan mengukur tingkat keuntungan dengan menggunakan rasio profitabilitas, rasio ini digunakan untuk mengukur tingkat imbalan atau perolehan (keuntungan) dari layanan jasa (produk) perbankan. Dalam beberapa penelitian untuk mengukur kinerja keuangan menggunakan Rate of Return on Total Assets (ROA) yang digunakan untuk mengukur kemampuan dari modal yang diinvestasikan dalam keseluruhan aktiva untuk menghasilkan keuntungan netto. ${ }^{9}$

Dari pemaparan di atas mengenai keuangan inklusif dan dampaknya pada unbanked people melalui perbankan syariah merupakan solusi agar masyarakat dapat mengakses jasa keuangan. Perbankan syariah merupakan perantara dari kebijakan keuangan inklusif tersebut, yang berhasil tidaknya dapat dilihat dari kinerja keuangan suatu perbankan syariah. Semakin banyak masyarakat yang menggunakan jasa keuangan, maka profitabilitas perbankan syariah semakin meningkat. Semakin meningkat profitabilitas perbankan syariah, maka semakin tinggi tingkat keuangan inklusif. Hal ini berarti jasa keuangan dapat diakses oleh masyarakat secara luas. Dalam penelitian ini objek yang dipilih oleh peneliti adalah perbankan syariah, lebih tepatnya Unit Usaha Syariah dikarenakan pada beberapa penelitian lain tingkat keuagan inklusif dan kinerja keuangan (ROA) pada Unit Usaha Syariah lebih stabil daripada Bank Umum Syariah dan Bank Pembiayaan Rakyat Syariah meskipun angkanya masih kecil. Dalam penelitian ini, akan menemukan pengaruh keuangan inklusif pada dimensi akses dan penggunaan di Unit Usaha Syariah. Maka dari itu, peneliti tertarik untuk

\section{“ Pengaruh Dimensi Akses dan Penggunaan pada Keuangan Inklusif terhadap Profitabilitas Unit Usaha Syariah di Indonesia Periode 2017-2019"}

\section{METODE PENELITIAN}

\section{A. Rancangan Penelitian}

Penelitian ini menggunakan pendekatan kuantitatif. Penelitian kuantitatif adalah jenis penelitian yang menghasilkan penemuan-penemuan yang dapat dicapai (diperoleh) dengan menggunakan prosedur-prosedur statistik atau cara-cara lain dari kuantifikasi (pengukuran). Pendekatan kuantitatif memusatkan perhatian pada gejala-gejala yang mempunyai

7 Priska Trias Agustin dan Ari Darmawan, "Pengaruh Rasio Keuangan Terhadap Kinerja Keuangan Bank Syariah (Studi pada Bank Umum Syariah yang Terdaftar di Otoritas Jasa Keuangan Republik Indonesia Tahun 2014-2016)," Jurnal Administrasi Bisnis, 1, 64 (November 2018): 103.

8 V.Wiratna Sujarweni, Manajemen Keuangan: Teori, Aplikasi dan Hasil Penelitian (Yogyakarta: Pustaka Baru Press, t.t), 109.

9 Sujarweni, 114.

Iqtishadia: Jurnal Ekonomi dan Perbankan Syariah 
karakteristik tertentu di dalam kehidupan manusia yang dinamakannya sebagai variabel. Dalam pendekatan kuantitatif hakikat hubungan diantara variabel-variabel dianalisis dengan menggunakan teori yang objektif.10 Metode penelitian kuantitatif dapat diartikan sebagai metode penelitian yang berlandaskan pada filsafat positivisme, digunakan untuk meneliti pada populasi atau sampel tertentu, teknik pengambilan sampel pada umumnya dilakukan secara random, pengumpulan data menggunakan instrumen penelitian, analisis data bersifat kuantitatif/statistik dengan tujuan untuk menguji hipotesis yang telah ditetapkan. ${ }^{11}$

Jenis penelitian ini adalah penelitian kuantitatif asosiatif. Penelitian asosiatif merupakan suatu penelitian yang bertujuan untuk mengetahui pengaruh dua variabel atau lebih. ${ }^{12}$ Metode analisis data yang digunakan dalam penelitian ini adalah analisis regresi linier berganda, untuk mengetahui pengaruh variabel bebas (variabel $\mathrm{X}_{1}$ dan $\mathrm{X}_{2}$ ) terhadap variabel terikat (variabel Y). Variabel bebas adalah variabel yang mempengaruhi atau yang menjadi sebab perubahan atau timbulnya variabel terikat. Sedangkan variabel terikat adalah variabel yang dipengaruhi atau yang menjadi akibat.13 Dalam penelitian ini, pengaruh variabel yang dimaksud adalah dimensi akses (variabel $X_{1}$ ) dimensi penggunaan (variabel $X_{2}$ ) pada keuangan inklusif terhadap profitabilitas (variabel Y) pada Unit Usaha Syariah di Indonesia periode 2017-2019.

\section{B. Populasi dan Sampel}

\section{Populasi}

Populasi (population), yaitu sekelompok orang, kejadian atau segala sesuatu yang mempunyai karakteristik tertentu. ${ }^{14}$ Populasi adalah keseluruhan jumlah yang terdiri atas objek atau subjek yang mempunyai karakteristik dan kualitas tertentu yang ditetapkan oleh peneliti untuk diteliti dan kemudian ditarik kesimpulannya. ${ }^{15}$

Jenis populasi dapat dibedakan menjadi dua, yaitu: ${ }^{16}$
a. Populasi yang Terbatas
b. Populasi Tidak Terbatas

\section{Sampel}

Sampel didefinisikan sebagai bagian atau subset dari populasi yang terdiri dari anggota-anggota populasi yang terpilih. Secara sederhana dapat dikatakan bahwa semua anggota sampel adalah anggota populasi, tetapi tidak semua anggota pupulasi adalah anggota

10 V. Wiratna Sujarweni, Metodologi Penelitian : Bisnis dan Ekonomi (Yogyakarta: Pustaka Baru Press, 2019), 39.

11 Ananta Wikrama Tungga A., Komang Adi Kurniawan Saputra, dan Diota Prameswari Vijaya, Metodologi Penelitian Bisnis (Yogyakarta: Graha Ilmu, 2014), 11.

12 Ahmad Tanzeh dan Suyitno, Dasar-Dasar Penelitian (Surabaya: Lembaga Kajian Agama dan Filsafat (eLKAF), 2006), 45.

13 Sugiyono, Metode Penelitian Bisnis : Pendekatan Kuantitatif, Kualitatif, dan R\&D (Bandung: Alfabeta, 2012), 59.

14 Nur Indriantoro dan Bambang Supomo, Metodologi Penelitian Bisnis (Yogyakarta: CV Andi Offset, 2018), 113.

15 Sujarweni, Metodologi Penelitian : Bisnis dan Ekonomi, 80.

16 Sugiarto,Sugiarto, Metodologi Penelitian Bisnis (Yogyakarta: CV Andi Offset, 2017), 135.

180 
sampel. ${ }^{17}$ Teknik sampling adalah teknik pengambilan sampel.18 Pengambilan sampel (sampling) adalah proses memilih sejumlah elemen secukupnya dari populasi, sehingga penelitian terhadap sampel dan pemahaman tentang sifat atau karakteristiknya akan membuat kita dapat mengeneralisasikan sifat atau karakteristik tersebut pada elemen populasi. ${ }^{19}$

\section{Sumber Data}

Sumber data dalam penelitian adalah subjek dari mana data dapat diperoleh. ${ }^{20}$ Sumber data dalam penelitian ini adalah data sekunder. Data sekunder merupakan sumber data penelitian yang diperoleh peneliti secara tidak langsung melalui media perantara (diperoleh dan dicatat oleh pihak lain). Data sekunder umumnya berupa bukti, catatan atau laporan historis yang telah tersusun dalam arsip (data dokumenter) yang dipublikasikan dan yang tidak dipublikasikan. ${ }^{21}$ Data sekunder merupakan data primer yang diperoleh oleh pihak lain atau data primer yang telah diolah lebih lanjut dan disajikan baik oleh pengumpul data primer atau oleh pihak lain dalam bentuk tabel-tabel atau diagram-diagram. ${ }^{22}$

Data yang digunakan dalam penelitian ini adalah Statistik Perbankan Syariah (SPS) yang diterbitkan setiap bulan oleh OJK dan data penduduk dewasa yang diterbitkan oleh BPS periode 2017-2019.

\section{Instrumen Penelitian}

Instrumen penelitian adalah alat atau fasilitas yang digunakan oleh peneliti dalam mengumpulkan data agar pekerjaannya lebih mudah dan hasilnya lebih baik, dalam arti lebih cermat, lengkap, dan sistematis sehingga lebih mudah diolah. Instrumen yang digunakan untuk mengumpulkan data dalam penelitian ini berupa dokumentasi. Dokumentasi, dari asal katanya dokumen, yang artinya barang-barang tertulis. Di dalam melaksanakan metode dokumentasi, peneliti menyelidiki benda-benda tertulis seperti buku-buku, majalah, dokumen, peraturan-peraturan, notulen rapat, catatan harian, dan sebagainya. ${ }^{23}$

\section{E. Pengumpulan Data}

Langkah-langkah yang akan dilakukan peneliti dalam pengumpulan data dengan dokumentasi yaitu:

b. Peneliti mengakses data di website resmi OJK dan BPS.

c. Peneliti mengunduh data per bulan dari Statistik Perbankan Syariah (SPS) OJK dan data penduduk dewasa yang diterbitkan oleh BPS periode 2016-2019.

17 Zulganef, Metode Penelitian Sosial \& Bisnis (Yogyakarta: Expert, 2018), 136.

18 Sugiyono, Metode Penelitian Kombinasi (Mixed Methods) (Bandung: Alfabeta, 2016), 121.

19 Wikrama Tungga A., Adi Kurniawan Saputra, dan Prameswari Vijaya, Metodologi Penelitian Bisnis, 82.

20 Suharsimi Arikunto, Prosedur Penelitian : Suatu Pendekatan Praktik (Jakarta: Rineka Cipta, 2006), 129.

21 Indriantoro dan Supomo, Metodologi Penelitian Bisnis, 143.

22 Sugiarto, Metodologi Penelitian Bisnis, 202.

23 Arikunto, Prosedur Penelitian : Suatu Pendekatan Praktik, 158.

Iqtishadia: Jurnal Ekonomi dan Perbankan Syariah

Vol. 8 No. 2 Desember 2021 
d. Peneliti melakukan penghitungan dimensi akses dan penggunaan pada keuangan inklusif, dengan rumus sebagai berikut:24

1. Menghitung dimensi akses dengan rumus sebagai berikut:

$\frac{\text { Jumlah ATM }}{\text { Jumlah Penduduk Dewasa }} \quad$ X 100.000

2. Menghitung dimensi penggunaan dengan rumus sebagai berikut:

$$
\begin{gathered}
\text { Jumlah Rekening Tabungan } \\
\text { Jumtah Penduduk Dewasa }
\end{gathered}
$$

e. Peneliti melakukan penghitungan kinerja keuangan dari sisi profitabilitas dengan menggunakan Rate of Return an Total Assets/ROA, dengan rumus sebagai berikut: 25

Laba Sebelum Bunga dan Pajak

Total Aktiva

\section{F. Analisis Data}

Analisis data merupakan kegiatan mengelompokkan data berdasarkan variabel dan jenis responden, mentabulasi data berdasarkan variabel dari seluruh responden, menyajikan data tiap variabel yang diteliti, melakukan perhitungan untuk menjawab rumusan masalah, dan melakukan perhitungan untuk menguji hipotesis yang telah diajukan. ${ }^{26}$

Teknik analisis data dalam penelitian kuantitatif menggunakan statistik. ${ }^{27}$ AnalisIs data dalam rencana penelitian ini dilakukan dengan menggunakan program SPSS. Langkahlangkah dalam menganalisis data dalam penelitian ini, yaitu:

1. Mencari Data Mentah

2. Statistik Deskriptif

3. Uji Asumsi Klasik

4. Pengujian Hipotesis

5.

\section{DESKRIPSI DAN PEMBUKTIAN HIPOTESIS}

\section{A. Deskripsi}

24 Soetiono dan Setiawan, LITERASI DAN INKLUSI KEUANGAN INDONESIA, 120.

25 Sujarweni, Manajemen Keuangan: Teori, Aplikasi dan Hasil Penelitian, 114.

26 Sugiyono, Metode Penelitian Bisnis : Pendekatan Kuantitatif, Kualitatif, dan R\&D, 206.

27 Wikrama Tungga A., Adi Kurniawan Saputra, dan Prameswari Vijaya, Metodologi Penelitian Bisnis, 91.

182 


\section{Deskripsi Objek Penelitian}

Unit Usaha Syariah merupakan unit kerja dari kantor pusat Bank Umum Konvensional yang berfungsi sebagai kantor induk dari kantor atau unit yang melaksanakan kegiatan usaha berdasarkan prinsip Syariah. Hingga juni 2019 jumlah Unit Usaha Syariah di Indonesia berjumlah 20 perusahaan.

Tabel 4.1

Daftar Unit Usaha Syariah di Indonesia

\begin{tabular}{cl} 
No. & \multicolumn{1}{c}{ Nama Perusahaan } \\
1 & PT. Bank Danamon Indonesia, Tbk \\
2 & PT. Bank Permata, Tbk \\
3 & PT. Bank Maybank Indonesia, Tbk \\
4 & PT. Bank CIMB Niaga, Tbk \\
5 & PT. Bank OCBC NISP, Tbk \\
6 & PT. Bank Sinarmas \\
7 & PT. Bank Tabungan Negara (Persero), Tbk \\
8 & PT. BPD DKI \\
9 & PT. BPD Daerah Istimewa Yogyakarta \\
10 & PT. BPD Jawa Tengah \\
11 & PT. BPD Jawa Timur, Tbk \\
12 & PT. BPDmatera Utara \\
13 & PT. BPD Jambi \\
14 & PT. BPD Sumatera Barat \\
15 & PT. BPD Riau dan Kepulauan Riau \\
16 & PT. BPD Sumatera Selatan dan Bangka Belitung \\
17 & PT. BPD Kalimantan Selatan \\
18 & PT. BPD Kalimantan Barat \\
19 & PT. BPD Kalimantan Timur \\
20 & PT. BPD Sulawesi Selatan dan Sulawesi Barat \\
Statistik Perbankan Syariah Desember 2019
\end{tabular}

Secara struktural, kegiatan Unit Usaha Syariah tidak terlepas dari bagian Bank Umum Konvensioanal. Namun, segala aktivitas layanan jasa keuangan tetap diawasi Dewan Pengawas Syariah (DPS) seperti bank Syariah pada umumnya.

Gambar 4.1

Struktur Unit Usaha Syariah

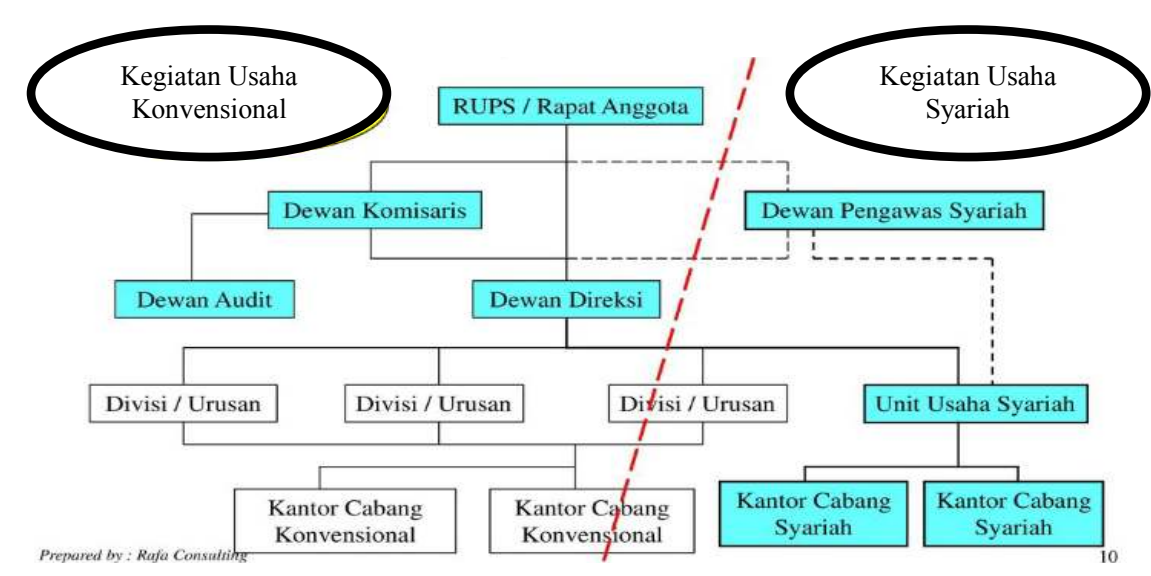




\section{B. Pembuktian Hipotesis}

\section{Analisis Regresi Linear Berganda}

Analisis regresi linear berganda digunakan untuk meramalkan nilai pengaruh dua variabel independent (dimensi akses dan penggunaan pada keuangan inkluisf) atau lebih terhadap variabel dependent (profitabilitas). Model regresi linear berganda sebagai berikut:

$Y=a+b_{1} X_{1}+b_{2} X_{2}+e$

Hasil analisis menggunakan SPSS (Statistic Package for The Socia Science) versi 24, dipeloreh sebagai berikut:

Tabel 4.8

Hasil Regresi Linear Berganda

\begin{tabular}{|c|c|c|c|c|c|c|}
\hline \multicolumn{7}{|c|}{ Coefficients $^{a}$} \\
\hline \multirow{2}{*}{\multicolumn{2}{|c|}{ Model }} & \multicolumn{2}{|c|}{$\begin{array}{l}\text { Unstandardized } \\
\text { Coefficients }\end{array}$} & \multirow{2}{*}{$\begin{array}{c}\begin{array}{c}\text { Standardized } \\
\text { Coefficients }\end{array} \\
\text { Beta }\end{array}$} & \multirow[b]{2}{*}{$\mathrm{t}$} & \multirow[b]{2}{*}{ Sig. } \\
\hline & & B & $\begin{array}{l}\text { Std. } \\
\text { Error }\end{array}$ & & & \\
\hline \multirow[t]{3}{*}{1} & (Constant) & 4.814 & .321 & & 15.017 & .000 \\
\hline & Dimensi Akses & -6.153 & 5.445 & -.168 & -1.130 & .267 \\
\hline & $\begin{array}{l}\text { Dimensi } \\
\text { Penggunaan }\end{array}$ & $\begin{array}{r}-1.576 \mathrm{E}- \\
5\end{array}$ & .000 & -.684 & -4.612 & .000 \\
\hline
\end{tabular}

Sumber: Data diolah

Analisis regresi linear berganda pada tabel di atas diperoleh koefisian variabel dimensi akses pada keuangan inklusif $=-6,153\left(\mathrm{X}_{1}\right)$, koefisian variabel dimensi penggunaan pada keuangan inklusif $=-0,00001576\left(\mathrm{X}_{2}\right)$ serta konstanta (a) sebesar 4.814. Sehingga model persamaan regresi linear berganda yang diperoleh dalam penelitian ini sebagai berikut:

$$
\mathrm{Y}=4,814-6,153 \mathrm{X}_{1}-0,00001576 \mathrm{X}_{2}
$$

Model persamaan regresi linear di atas dapat diinterpretasikan sebagai berikut: $\mathrm{a}=4,814$. Dalam kasus ini nilainya sebesar 4.814. Angka ini merupakan angka konstan yang mempunyai arti bahwa jika tidak ada keuangan inklusif, maka nilai konsisten profitabilitas sebesar 4,814 .

$b_{1}=-6,153$. Nilainya sebesar $-6,153$. Koefisien regresi bernilai negatif menunjukkan adanya hubungan yang tidak searah antara dimensi akses pada keuangan inklusif dengan profitabilitas di Unit Usaha Syariah periode 2017-2019. Semakin tinggi nilai dimensi akses pada keuangan inklusif, maka semakin rendah profitabilitas di Unit Usaha Syariah. Artinya, setiap kenaikan $1 \%$ tingkat keuangan inklusif, maka profitabilitas akan menurun sebesar 6,153 .

$\mathrm{b}_{2}=-0,00001576$. Nilainya sebesar $-0,00001576$. Koefisien regresi bernilai negatif menunjukkan adanya hubungan yang tidak searah antara dimensi penggunaan pada keuangan inklusif dengan profitabilitas di Unit Usaha Syariah periode 2017-2019. Semakin 
tinggi nilai dimensi penggunaan pada keuangan inklusif, maka semakin rendah profitabilitas di Unit Usaha Syariah. Artinya, setiap penambahan 1\% tingkat keuangan inklusif, maka profitabilitas akan menurun sebesar 0,0001576.

\section{Uji t}

Uji signifikan individual dua variabel bebas terhadap variabel terikat digunakan untuk mengukur secara terpisah kontribusi yang ditimbulkan dari masing-masing variabel terhadap variabel terikat dengan $\alpha=0,05$ dari pengambilan keputusan sebagai berikut:

a. Jika $t_{\text {hitung }}<t_{\text {tabel }}$ atau nilai signifikasi $>0,05$ maka variabel independen secara individual tidak berpengaruh terhadap variabel dependen.

b. Jika $t_{\text {hitung }}>t_{\text {tabel }}$ nilai signifikasi $<0,05$ maka variabel independen secara individual berpengaruh terhadap variabel dependen.

Berikut ini adalah hasil uji signifikansi secara parsial (individual) variabel independen:

\section{Tabel 4.9}

Hasil Uji t

\begin{tabular}{|c|c|c|c|c|c|c|}
\hline \multicolumn{7}{|c|}{ Coefficients $^{a}$} \\
\hline & & \multicolumn{2}{|c|}{$\begin{array}{l}\text { Unstandardized } \\
\text { Coefficients }\end{array}$} & \multirow{2}{*}{$\begin{array}{c}\text { Standardized } \\
\text { Coefficients } \\
\text { Beta }\end{array}$} & \multirow[b]{2}{*}{$\mathrm{t}$} & \multirow[b]{2}{*}{ Sig. } \\
\hline \multicolumn{2}{|c|}{ Model } & B & $\begin{array}{l}\text { Std. } \\
\text { Error }\end{array}$ & & & \\
\hline \multirow[t]{3}{*}{1} & (Constant) & 4.814 & .321 & & 15.017 & .000 \\
\hline & Dimensi Akses & -6.153 & 5.445 & -.168 & -1.130 & .267 \\
\hline & $\begin{array}{l}\text { Dimensi } \\
\text { Penggunaan }\end{array}$ & $\begin{array}{r}-1.576 \mathrm{E}- \\
5\end{array}$ & .000 & -.684 & -4.612 & .000 \\
\hline
\end{tabular}

Sumber: Data diolah

Berdasarkan hasil analisis uji parsial $(\mathrm{t})$ pada tabel diatas, pengaruh masing-masing variabel dijelaskan sebagai berikut:

Variabel dimensi akses pada keuangan inklusif $\left(\mathrm{X}_{1}\right)$ diperoleh nilai $t_{\text {hitung }}$ sebesar $-1,130$ dan $t_{\text {tabel }}$ sebesar 2,03224. Hasil uji tersebut menunjukkan bahwa nilai $t_{\text {hitung }}-1,130<t_{\text {tabel }}$ 2,03224, dengan demikian dapat disimpulkan bahwa variabel dimensi akses pada keuangan inklusif $\left(\mathrm{X}_{1}\right)$ tidak berpengaruh terhadap profitabilitas di Unit Usaha Syariah.

Variabel dimensi penggunaan pada keuangan inklusif $\left(\mathrm{X}_{2}\right)$ diperoleh nilai $t_{\text {hitung }}$ sebesar $-4,612$ dan $t_{\text {tabel }}$ sebesar 2,03224. Hasil uji tersebut menunjukkan bahwa nilai $t_{\text {hitung }}-4,612>$ $t_{\text {tabel }} 2,03224$, dengan demikian dapat disimpulkan bahwa variabel dimensi penggunaan pada keuangan inklusif $\left(\mathrm{X}_{2}\right)$ berpengaruh negatif terhadap profitabilitas di Unit Usaha Syariah.

\section{Uji F}

Uji F dilakukan untuk mengetahui besarnya pengaruh variabel bebas secara bersamasama antara variabel independen terhadap variabel dependen dengan pengambilan keputusan sebagai berikut: 
a. Jika $F_{\text {hitung }}<\mathrm{F}_{\text {tabel }}$ atau nilai signifikasi $>0,05$ maka variabel bebas tidak berpengaruh pada variabel terikat.

b. Bila $F_{\text {hitung }}>F_{\text {tabel }}$ atau nilai signifikasi $<0,05$ maka variabel bebas berpengaruh pada variabel terikat.

Berikut ini adalah hasil uji signifikansi secara simultan (bersama-sama) variabel independen:

Tabel 4.10

Hasil Uji F

\begin{tabular}{|l|l|r|r|r|r|c|}
\hline \multicolumn{7}{|c|}{ ANOVA $^{\mathrm{a}}$} \\
\hline \multirow{2}{*}{\begin{tabular}{l} 
Model \\
\hline 1
\end{tabular}} & $\begin{array}{c}\text { Sum of } \\
\text { Squares }\end{array}$ & $\mathrm{df}$ & Mean Square & F & Sig. \\
\cline { 2 - 8 } & Regression & 2.249 & 2 & 1.125 & 32.486 & $.000^{\mathrm{b}}$ \\
\cline { 2 - 8 } & Residual & 1.142 & 33 & .035 & & \\
\cline { 2 - 7 } & Total & 3.391 & 35 & & & \\
\hline
\end{tabular}

Sumber: Data diolah

Berdasarkan hasil Uji F pada tabel diatas dapat diperoleh nilai $F_{\text {hitung }}$ sebesar 32,486 dan nilai $\mathrm{F}_{\text {tabel }}$ untuk model regresi tersebut yaitu 3,28. Hasil uji tersebut menujukkan bahwa nilai $\mathrm{F}_{\text {hitung }} 32,486>\mathrm{F}_{\text {tabel }} 3,28$, dengan demikian keputusannya adalah variabel $\mathrm{X}$ (dimensi akses dan penggunaan pada keuangan inklusif) berpengaruh secara simultan terhadap profitabilitas pada Unit Usaha Syariah di Indonesia.

\section{Koefisien Determinasi $\left(R^{2}\right)$}

Koefisien determinasi $\left(\mathrm{R}^{2}\right)$ digunakan untuk mengukur seberapa jauh kemampuan model regresi dalam menerangkan variabel independen. Koefisien ini digunakan untuk mengetahui besarnya pengaruh variabel independen terhadap variabel independen. Nilai koefisien ini adalah antara nol sampai dengan satu. Apabila nilainya kecil berarti kemampuan variabel-variabel independen dalam menjelaskan variabel dependen sangat terbatas. Apabila nilai $\mathrm{R}^{2}$ mendekati satu berarti variabel-variabel independent mampu memberikan hamper semua informasi yang dibutuhkan untuk memprediksi variabel dependen.

\section{Tabel 4.11}

\section{Hasil Uji Koefisien Determinasi}

\begin{tabular}{|l|c|r|r|r|}
\hline \multicolumn{5}{|c|}{ Model Summary } \\
\hline Model & $\mathrm{R}$ & R Square & $\begin{array}{c}\text { Adjusted R } \\
\text { Square }\end{array}$ & $\begin{array}{c}\text { Std. Error of } \\
\text { the Estimate }\end{array}$ \\
\hline 1 & $.814^{\mathrm{a}}$ & .663 & .643 & .18605 \\
\hline
\end{tabular}

Sumber: Data diolah

Berdasarkan tabel diatas dapat diketahui bahwa nilai R Square sebesar 0, 663. Hal ini menunjukkan bahwa variabel independen (Dimensi akses dan penggunaan pada keuangan inklusif) dapat menerangkan variabel dependen (Profitabilitas) sebesar $66,3 \%$. Sedangkan sisanya 33,7 \%(100\% - 66,3\% = 33,7\%) diterangkan oleh variabel lain yang tidak dimasukkan dalam model regresi di penelitian ini.

\section{PENUTUP}




\section{Kesimpulan}

Berdasarkan hasil analisis data dan pengujian hipotesisi pada penelian ini tentang Pengaruh Dimensi Akses dan Penggunaan pada Keuangan Inklusif terhadap Profitabilitas Unit Usaha Syariah di Indonesia Periode 2017-2019 maka dapat ditarik kesimpulan sebagai berikut:

1. Berdasarkan hasil uji t, variabel dimensi akses pada keuangan inklusif $\left(\mathrm{X}_{1}\right)$ diperoleh nilai $t_{\text {hitung }}$ sebesar $-1,130$ dan $t_{\text {tabel }}$ sebesar 2,03224. Hasil uji tersebut menunjukkan bahwa nilai $t_{\text {hitung }}-1,130<t_{\text {tabel }} 2,03224$, dengan demikian dapat disimpulkan bahwa variabel dimensi akses pada keuangan inklusif $\left(\mathrm{X}_{1}\right)$ tidak berpengaruh terhadap profitabilitas di Unit Usaha Syariah karena kemampuan dan dukungan teknologi informasi masih terbatas dan jumlah ketersediaan mesin ATM masih sedikit dibandingkan dengan Bank Umum Syariah.

2. Berdasarkan hasil uji $t$, variabel dimensi penggunaan pada keuangan inklusif $\left(\mathrm{X}_{2}\right)$ diperoleh nilai $t_{\text {hitung }}$ sebesar $-4,612$ dan $t_{\text {tabel }}$ sebesar 2,03224. Hasil uji tersebut menunjukkan bahwa nilai $t_{\text {hitung }}-4,612>t_{\text {tabel }} 2,03224$, dengan demikian dapat disimpulkan bahwa variabel dimensi penggunaan pada keuangan inklusif $\left(\mathrm{X}_{2}\right)$ signifikan berpengaruh negatif terhadap profitabilitas di Unit Usaha Syariah karena keterbatasan jangkauan lembaga keuangan sehingga unbanked people memilih layanan keuangan informal. Sedangkan tingkat profitabilitas di Unit Usaha Syariah masih fluktiatif dan biaya operasional yang dikeluarkan lumayan besar.

3. Berdasarkan analisis koefisien determinasi membuktikan nilai R Square sebesar 0, 663. Hal ini menunjukkan bahwa variabel independen (dimensi akses dan penggunaan pada keuangan inklusif) dapat menerangkan variabel dependen (Profitabilitas) sebesar 66,3\%. Sedangkan 33,7 \% diterangkan oleh variabel lain. Dan berdasarkan hasil analisis data pengujian hipotesis, uji $\mathrm{F}$ pada penelitian ini dapat diketahui bahwa nilai $\mathrm{F}_{\text {hitung }}$ sebesar 32,486 dengan tingkat signifikasi sebesar 0,000 . Nilai $F_{\text {tabel }}$ sebesar 3,28. Hasil uji tersebut menujukkan bahwa nilai signifikasi $0,000<0,05$ dan nilai $F_{\text {hitung }} 32,486>F_{\text {tabel }} 3,28$. Sehingga dengan demikian membuktikan bahwa variabel $\mathrm{X}$ (dimensi akses dan penggunaan pada keuangan inklusif) berpengaruh secara simultan terhadap profitabilitas pada Unit Usaha Syariah di Indonesia periode 2017-2019 karena perbankan merupakan lembaga jasa keuangan yang efektif dalam penerapan keuangan inklusif di Indonesa dibandingan dengan jasa keuangan lainnya.

\section{DAFTAR PUSTAKA}

Aji Mardani, Dede. "Peran Perbankan Syariah Dalam Mengimplementasikan Keuangan Inklusif Di Indonesia." Al-Afkar: Journal for Islamic Studies, 1, 1 (Januari 2018).

Arikunto, Suharsimi. Prosedur Penelitian : Suatu Pendekatan Praktik. Jakarta: Rineka Cipta, 2006.

Asyatun, Irma. "REGIONAL AND ACCESSIBILITY ANALYSIS OF THE BANKING SYSTEM AND THEIR IMPACTS TOWARD REGIONAL FINANCIAL INCLUSION IN INDONESIA." Journal of Islamic Monetary Economics and Finance, 2, 4 (November 2018).

Bank Indonesia. BOOKLET KEUANGAN INKLUSIF, 2014.

Bonivia, Trevie Della, Hasdi Aimon, dan Alpon Satrianto. "PENGARUH FINANCIAL INCLUSION TERHADAP PEREKONOMIAN INDONESIA." Jurnal Kajian Ekonomi dan Pembangunan, 3, 1 (Agustus 2019). 
Fahmi, Irham. Manajemen Keuangan Perusahaan dan Pasar Modal. Jakarta: Mitra Wacana Media, 2014.

Fauziyah, Ayu Febriyanti, dan Nurul Hidayatin Nisa. "Inklusi Keuangan dan sistem Keuangan (Bank Z-Score) di Asia." Optimal: JURNAL EKONOMI DAN KEWIRAUSAHAAN, 1, 14 (2020).

Hasan, Iqbal. Analisis Data Penelitian dengan Statistik. Jakarta: Bumi Aksara, 2004.

Indonesia, Republik. Undang-Undang Republik Indonesia Nomor 10 Tahun 1998 (1998).

- - - Undang-Undang Republik Indonesia Nomor 21 Tahun 2008 Tentang Perbankan Syariah. (2008).

Indriantoro, Nur, dan Bambang Supomo. Metodologi Penelitian Bisnis. Yogyakarta: CV Andi Offset, 2018.

Ismail. Perbankan Syariah. Jakarta: PRENADAMEDIA GROUP, 2011.

Keuangan, Otoritas Jasa. "Snapshot Perbankan Syariah Indonesia 2019." Otoritas Jasa keuangan, Maret 2019.

Kuncoro, Mudrajat. Metode Kuantitatif: Teori dan Aplikasi untuk Bisnis dan Ekonomi. Yogyakarta: Sekolah Tinggi Ilmu Manajemen YKPN, 2011.

Machali, Imam. METODE PENELITIAN KUANTITATIF: Panduan Praktis Merencanakan, Melaksanakan dan Analisis dalam Penelitian Kuantitatif. Yogyakarta: UIN Sunan Kalijaga, 2017.

Nasution, Yasir Nasution,dkk, Hairatunnisa. "Analisis Financial Inclusion Terhadap Pemberdayan Mayarakat Miskin di Medan (Studi Kasus Pembiayaan Mikro SS II di Bank Sumut Syariah)." j-EBIS: Jurnal Ekonomi dan Bisnis Islam, 1, 2 (April 2017).

Nursyam, Elsa Septiani, dan Azib. "Pengaruh Keuangan Inklusif (Financial Inclusion) pada Dimensi Akses (Access) dan Dimensi Penggunaan (Usage) terhadap Profitabilitas." Prosiding Manajemen, 1, 6 (2020).

Otoritas Jasa keuangan. Peraturan Otoritas Jasa Keuangan Nomor 76/PJOK.07/2016 tentang Peningkatan Literasi dan Inklusi Keuangan Sektor Jasa Keuangan Bagi Konsumen dan/atau Masyarakat (2016).

Presiden Rebuplik Indonesia. Peraturan Presiden Rebuplik Indonesia Nomor 114 Tahun 2020 tentang Straegi Nasional Keuangan Inklusif (2020).

Presiden Republik Indonesia. Peraturan Presiden Republik Indonesia Nomor 42 Tahun 2016 tentang Strategi Nasional Keuangan Inklusif (2016).

Rusman, Tedi. STATISTIKA PENELITIAN: Aplikasinya dengan SPSS. Yogyakarta: Graha Ilmu, 2015.

Sarwono, Jonathan. Buku Pintar IBM SPSS Statistics 19. Jakarta: PT Elex Media Komputindo, 2011.

Septiana, Aldila. ANALISIS LAPORAN KEUANGAN: Konsep Dasar dan Deskripsi Laporan Keuangan. Pamekasan: DUTA MEDIA PUBLISHING, 2019.

Siregar, Syofian. Statistika Deskriptif untuk Penelitian: Dilengkapi Perhitungan Manual dan Aplikasi SPSS Versi 17. Jakarta: Rajawali Pers, 2012.

Soetiono, Kusumaningtuti S., dan Cecep Setiawan. LITERASI DAN INKLUSI KEUANGAN INDONESIA. Depok: PT RAJAGRAFINDO PERSADA, 2018.

Sugiarto. Metodologi Penelitian Bisnis. Yogyakarta: CV Andi Offset, 2017.

Sugiyanto, Catur. Ekonometrika Edisi 1. Banten: Universitas Terbuka, 2017.

Sugiyono. Metode Penelitian Bisnis: Pendekatan Kuantitatif, Kualitatif, dan R\&D. Bandung: Alfabeta, 2012.

_-_. Metode Penelitian Kombinasi (Mixed Methods). Bandung: Alfabeta, 2016. 
Sujarweni, V. Wiratna. Metodologi Penelitian : Bisnis dan Ekonomi. Yogyakarta: Pustaka Baru Press, 2019.

Sujarweni, V.Wiratna. Manajemen Keuangan: Teori, Aplikasi dan Hasil Penelitian. Yogyakarta: Pustaka Baru Press, t.t.

Suroso, Sugeng. KINERJA BANK UMUM SYARIAH. Yogyakarta: expert, 2018.

Tanzeh, Ahmad, dan Suyitno. Dasar-Dasar Penelitian. Surabaya: Lembaga Kajian Agama dan Filsafat (eLKAF), 2006.

Tim Penyusun Pedoman Penulisan Karya Ilmiah. Pedoman Penulisan Karya Ilmiah. Pamekasan: STAIN Pamekasan, 2015.

Trias Agustin dan Ari Darmawan, Priska. "Pengaruh Rasio Keuangan Terhadap Kinerja Keuangan Bank Syariah (Studi pada Bank Umum Syariah yang Terdaftar di Otoritas Jasa Keuangan Republik Indonesia Tahun 2014-2016)." Jurnal Administrasi Bisnis, 1, 64 (November 2018).

Umar, Husein. Metode Penelitian untuk Skripsi dan Tesis Bisnis. Jakarta: Rajawali Pers, 2013.

Uzhma, Khalifatul. "Analisis Pengaruh Keuangan Inklusif terhadap Profitabilitas pada Perbankan Syariah di Indonesia." Skripsi,Universitas Islam Negeri Syarif Hidayatullah Jakarta, 2017.

Wijaya, Rendi. "Analisis Perkembangan Return On Assets (ROA) dan Return On Equity (ROE) Untuk Mengukur Kinerja keuangan." Jurnal Imu Manajemen 9 (2019).

Wikrama Tungga A., Ananta, Komang Adi Kurniawan Saputra, dan Diota Prameswari Vijaya. Metodologi Penelitian Bisnis. Yogyakarta: Graha Ilmu, 2014.

Zulganef. Metode Penelitian Sosial \& Bisnis. Yogyakarta: expert, 2018.

Al-Qur'an,al-Maidah (5):2.

"Elektronifikasi dan Keuangan Inklusif" Bank Sentral Republik Indonesia, diakses dari https://www.bi.go.id/id/edukasi/Pages/Elektonifikasi-dan-Keuangan-Inklusi.aspx pada tanggal 15 Februari 2020 pukul 15.27 WIB.

"Indeks Keuangan Inklusif," Bank Sentral Republik, diakses dari https://www.bi.go.id/id/perbankan/keuanganinklusif/indikator/indeks/contents/def ault.aspx pada 6 November 2020 pukul 12.07 WIB.

"Keuangan Inklusif di Indonesia" Bank Sentral Republik Indonesia, diakses dari, https://www.bi.go.id/id/perbankan/keuanganinklusif/Indonesia/Contents/Default.as px pada tanggal 9 April 2021 pukul 11.09 WIB.

"Keuangan Inklusif" Bank Sentral Republik Indonesia, diakses dari https://www.bi.go.id/id/fungsi-utama/stabilitas-sistem-keuangan/keuanganinklusif/Default.aspx pada tanggal 22 Februari 2021 pukul 10.09 WIB. 